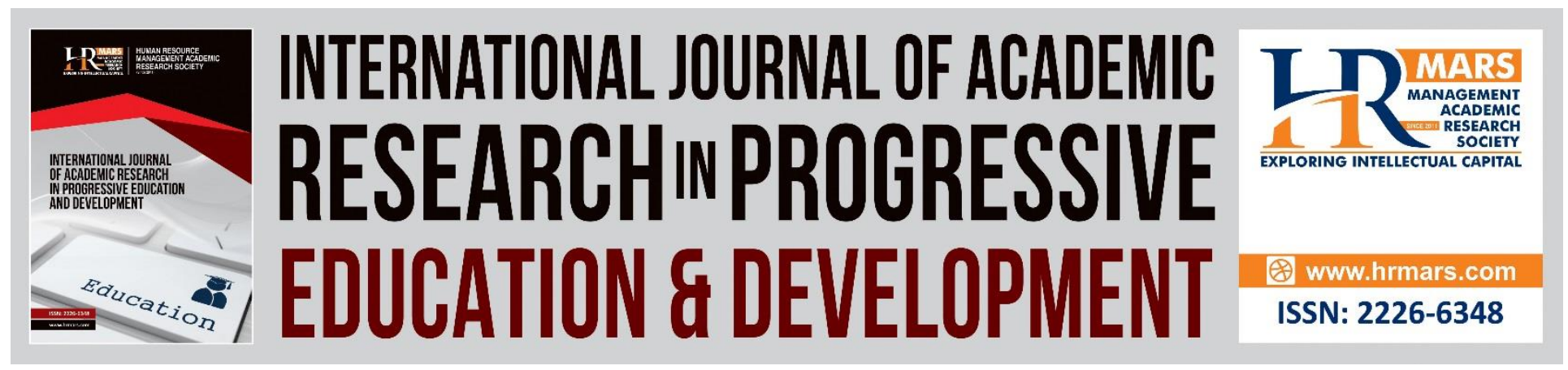

\title{
Lesson Learned from Coaches of Malaysia National Football Development Programme (NFDP): Preferred Career Development Pathway and Acrredited Coaching Course
}

\section{Zulakbal Bin Abd Karim \& Najib Razak}

To Link this Article: http://dx.doi.org/10.6007/IJARPED/v7-i3/4565

DOI: $10.6007 /$ IJARPED/v7-i3/4565

Received: 03 June 2018, Revised: 23 June 2018, Accepted: 03 July 2018

Published Online: 28 July 2018

In-Text Citation: (Karim \& Razak, 2018)

To Cite this Article: Karim, Z. B. A., \& Razak, N. (2018). Lesson Learned from Coaches of Malaysia National Football Development Programme (NFDP): Preferred Career Development Pathway and Acrredited Coaching Course. International Journal of Academic Research in Progressive Education and Development, 7(3), 465479.

\section{Copyright: (C) 2018 The Author(s)}

Published by Human Resource Management Academic Research Society (www.hrmars.com)

This article is published under the Creative Commons Attribution (CC BY 4.0) license. Anyone may reproduce, distribute, translate and create derivative works of this article (for both commercial and non-commercial purposes), subject to full attribution to the original publication and authors. The full terms of this license may be seen at: http://creativecommons.org/licences/by/4.0/legalcode

\section{Vol. 7, No. 3, July 2018, Pg. 465 - 479}

Full Terms \& Conditions of access and use can be found at http://hrmars.com/index.php/pages/detail/publication-ethics 


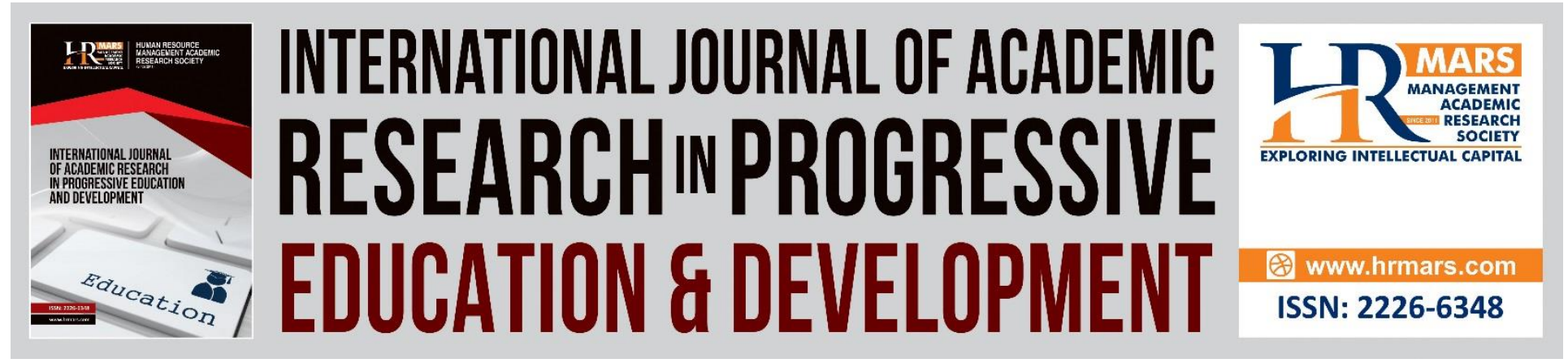

\title{
Lesson Learned from Coaches of Malaysia National Football Development Programme (NFDP): Preferred Career Development Pathway and Acrredited Coaching Course
}

\author{
Zulakbal Bin Abd Karim \& Najib Razak \\ Faculty of Sports Science and Coaching, Sultan Idris Education University, 35900, Tanjung \\ Malim, Perak, Malaysia \\ Email: zulakbal@fsskj.upsi.edu.my
}

\begin{abstract}
The issues surrounding players and coaches at the elite football in Malaysia have been addressed by a number of scholars. Ironically, however, grassroots football coaches, although many said their role are fundamental to the development of football, has rarely been explored in the academic literature. This study to date therefore, has tended to focus on the grassroots coaches in National Football Development Program (NFDP). The aims of this study has been to try and established what is the NFDP coaches preferred as their development pathways as well as pathways of their preferred formal accreditation processes. This research was guided by principles of grounded theory (GT) by Strauss and Corbin, (1990) investigating the development of expertise. This is a qualitative study that used a developed design concept, using a purposive sampling method. A total of seven participants (coaches) from the NFDP were interviewed to determine the current and existing development direction related to their coaching context and accreditation pathways. The findings showed that their interest or preferred development pathways and preferred accreditation content, are different from what is already in place provided by the national football governing body, that they believed able to enhance their coaching competency. It is recommended that NFDP governing body, utilized the results of this study to review its coaching course to meet the aspiration of its coaches and approach findings of this study as a guideline to relay its career development pathways to address the needs of their coaches to finally give benefit to the player's development. Researchers hope that proposed findings of this study can assist to improve the career path of the coaches in order to provide maximum impact to the national football development through NFDP.
\end{abstract}

Keywords: Football, Coach, Development Coach, Career Path Development, Sources of Knowledge 


\section{Introduction}

Football is of interest to all ages, from elementary school to adult, (Abdullah Ali \& Mad Dinos Talib, 2013). Football is considered by many as the number one sport in the world, as well as in Malaysia as it is considered as the number one sport based on television audiences, compared to other sporting events viewed (Hamid \& Kendall, 2008; Karim, 2016; Karim \& Nadzalan, 2017; Pundyk, 2004). There are various football structures in Malaysia ranging from grassroots to international level. At the grassroots level, football is managed by collaboration between the Football Association of Malaysia (FAM), the Ministry of Youth and Sports (KBS), the National Sports Council (MSN) and the Ministry of Education Malaysia (KPM) by producing a plan known as the National Football Development Program (NFDP). NFDP is a long-term plan where the first phase has started from 2014 to 2020. The NFDP mission is to create a systematic and comprehensive football development ecosystem towards increasing players' quantity and quality for the formation of great national football team (Ministry of Youth and Sports Malaysia, 2013). There are five strategic thrusts in NFDP program; i) forming style, ii) improving quality and building self-esteem with national football DNA, iii) identifying and forming national football heroes, iv) providing standards that meet all standards, and v) improving coaching development and strengthen the structure of the competition at various levels.

According to the Ministry of Youth and Sports, (2013) there are two phases in NFDP, Phase 1 (2014-2020) and Phase 2 (2021-2030). Phase 1 (2014-2020) is an early phase which will focus on; introduce national football DNA, intensify participation and competition for players from ages seven to 17 , restructure administration and management of development programs, enhance coordination between stakeholders, empower coaching programs and provide adequate basic amenities at all levels. Phase 2 (2021-2030) will focus on; implementing audits and assessments in Phase 1 (2014-2020), equipping football development ecosystems, streamlining the facilities of training centers that have been added to Phase 1 (2014- 2020), forming and educating more coaches at community, primary and secondary levels, enabling more partnerships with the private sector in strengthening the development of academies under the NFDP, opening opportunities and promoting players as well as coaches created under the program to professional markets, enhance the sustainability of the NFDP to be a regional model and draw up the research and development (R\&D) of sports especially football through collaboration with institutions of higher learning .

Referring to the fourth core of the NFDP that is to enhance the development of coaching, Phase 1 (2014-2020) which is to strengthen the coaching program, and Phase 2 (2021-2030) which is to form and educate more coaches at the level community, primary and secondary school, this program plan also emphasizes the most important individual in football sport, the coach. There are various issues highlighted in this regard. Among them are the coaches involved not receiving proper accreditation, lack of good technical knowledge, coaching license issues and coaching skills among the coaches themselves. Even so, is the goal set by the NFDP can be achieved if they do not cope or know what is the issue faced by each coach involved under this program? 
There are some key challenges faced by coaches in Malaysia, among them includes education curriculum for coaches, uncertainty in coaching direction, limited opportunities among coaches and guarantees of work as coaches (Karim \& Nadzalan, 2017a; Karim \& Nadzalan, 2017b). If the NFDP does not identify the issues faced by their coaches and understand what coaching knowledge sources are able to improve their coaching skills, then the goals of the program will not be fully achieved and players trained will not achieve the standard set. When this happens, the money and time spend will become a waste and the country will definitely face a negative impact especially on developing a great national football team. In this regard, a study should be conducted to determine the issues faced by the coaches under the NFDP program and to know what sources of knowledge provided by the program in their coaches the knowledge to achieve the objectives set by the program.

\section{Problem Statement}

Refers to the fourth core of the National Football Development Plan (NFDP) program that enhances the development of coaching, Phase 1 (2014-2020), which is to strengthen the coaching program and Phase 2 (2021-2030) program of forming and educating more coaches at the level community, primary and secondary school, this program plan also emphasizes the most important individual in football sport, the coach. However, a comprehensive plan has been set up by the NFDP authorities but is there a syllabus of coaching courses or coaching accreditation paths that have been prepared in line with the plan that has been set up?

There are various issues highlighted in this regard. Among them are the coaches involved not receiving proper accreditation, lack of good technical knowledge, coaching license issues and coaching skills among the coaches themselves. Even so, is the goal set by the National Football Development Plan (NFDP) to be achieved if they do not cope or know what is the issue faced by each trainer involved under this program?

According to Zulakbal Abd Karim, (2016) there are some key challenges faced by coaches in Malaysia, among them education curriculum for coaches, uncertainty in coaching direction, limited opportunities among coaches and guarantees of work as coaches. If the National Football Development Program (NFDP) blueprint does not identify the issues faced by their coaches and understand what coaching knowledge sources are able to improve their coaching skills, then the goals of the program will not be achieved and players trained do not achieve the standard set. When this happens, wasting tax payers money will also occur, time losses will be faced by coaches and players and will ultimately have a negative impact on the country's football.

As compared to the vast development and attention given to the players of NFDP, so far, however there has been little discussion about the development of the most important individual in the development of the players, the coach. The rapid increase of number of program and player's development must be parallel with the coach's development. 
INTERNATIONAL JOURNAL OF ACADEMIC RESEARCH IN PROGRESSIVE EDUCATION AND

DEVELOPMENT

Vol. 7, No. 3, July 2018, E-ISSN: 2226-6348 @ 2018 HRMARS

\section{Researh Objectives}

There are two objectives that researchers would like to achieve, namely general objectives and specific objectives.

The general objective of this study is to identify lesson learned from coaches of Malaysia National Football Development Plan (NFDP).

The specific objectives in this study are to;

1. To understand what is the syllabus content of accredited coaching courses the coaches preferred.

2. To discover what is the preferred coaching career development pathways based on the interests and tendencies of the coaches involved.

\section{Research Questions}

This study seeks to address the following questions:

1. Do the syllabus content of accredited coaching courses provided satisfy the coaches involved?

2. Do the current coaching career development pathways are based on the interests and tendencies of the coaches involved?

\section{Method}

This research was guided by principles of grounded theory (EGT), (Strauss \& Corbin, 1990) investigating the development of expertise. Grounded theory was selected because although it permits analytical techniques, it also enables a richer and deeper framework for understanding the complexity of development in the dynamic field of coaching development (Pellegrino, Chudowsky, \& Glaser, 2001).

\section{Participants}

Seven (7) participants were recruited based on the principles of theoretical sampling (Strauss \& Corbin, 1990, 1998). At the beginning of this study, however, a selective sampling strategy was used aimed at phenomenological variation followed by theoretical sampling. Consequently, and eventually a cross section of non-accredited, " $D$ " and " $C$ " license coaches were recruited that adequately represented the various levels, from grassroots and youth coaching at the NFDP center. 


\section{Data Collection}

Following the principle of Grounded Theory recommended by Strauss and Corbin (1990), data was collected, and was also conducted in accordance with methods recommended by Strauss and Corbin (1990), including in-depth interviews, observations, and research notes.

\section{Procedure}

The data collection for this study was conducted in Kuala Lumpur and Shah Alam in mid-2017. Once coaches agreed to participate, times for face-to-face interviews were arranged at mutually convenient locations. This study was also conducted during the off day of the season for NFDP Championship where we are able to organize interviews with many of the participants in an efficient and cost effective manner.

Participants were given information, and immediately prior to the interviews they were reminded of the purpose of the study, the risks and safeguards were given an opportunity to ask questions. In addition, they were offered opportunities to review the interview guide before participating. All the respondents consented to the interviews being digitally recorded and transcribed. Interviews followed a guide, ranging in length from 45 to 90 minutes. The interviews were then transcribed verbatim and analyzed using Grounded Theory (GT) methodology (Strauss \& Corbin, 1998).

Interviews

In-depth semi-structured interviews were used to explore how participants organized and understood their coaching experiences especially related to their coaching development pathways and their accredited coaching course. A semi-structured interview guide was used with a recursive design whereby newly identified themes could be explored in subsequent interviews. Furthermore, probe questions were also used to explore ideographic themes and issues relevant to each interviewee. Initially data analysis involved creating electronic written transcripts of the participant's answer during the interviews. To this end, interviews were recorded and transcribed verbatim resulting in 250 pages of single spaced text.

\section{Data Analysis}

\section{Coding and conceptualizing}

Following the Strauss and Corbin (1998) approach to data analysis, open coding, axial coding and selective coding techniques were used. According to Strauss and Corbin, a code is a concept, often reduced to a word that signifies what is essentially going on with a piece of data. Whereas, coding is the analytic process of examining data line by line or paragraph by paragraph for significant events, experiences, and feelings that are denoted as concepts.

\section{Open coding}

More than 2,000 codes were identified in this study using the open coding procedure. For open coding, at the initial stage of this study, microanalysis of the interview transcripts was carried out, with line-by-line analysis to identify potential themes and concepts in the data. An open 
Vol. 7, No. 3, July 2018, E-ISSN: 2226-6348 @ 2018 HRMARS

code was given to significant events, feelings and experiences denoted by the participants, for example "Accreditation". The accreditation represents the development pathways that coaches are aware of. In this study, the accreditation identified were identical to the accreditation stages identified in the FAM coaching license system. Following the Strauss and Corbin, (1990) approach and principle of Grounded Theory the Axial coding and selective coding were later used to build theories/ model in an inductive process.

\section{Axial coding}

Axial coding is "a set of procedures whereby data are put back together in new ways after open coding, by making connections between categories." Following the procedures recommended by Strauss and Corbin (1998), we later identified a central category, linking all the categories through a relationship statement using the selective coding procedure.

\section{Selective coding}

Selective coding was carried out after determining what was essentially the core variable. The core provides a clue to explain the behavior of the participants in resolving their main concerns. Interview guides and procedures were used with this NFDP coaches in Kuala Lumpur and Shah Alam and the core categories were identified from the data analysis (Preferred career development and preferred accredited coaching course pathways).

\section{Labelling codes}

During the Open Coding stage, once a concept was identified, a label was assigned to it using keywords. There were times when the codes were classified as in-vivo, whereby the label was extracted from the words used heavily by the interviewee. In vivo codes as mentioned by Saldana (2013) are codes taken directly from the text, usually in quotation marks. For example, one of the coaches mentioned the word "age related coaching course" in order to explain the course he needs to cater the needs he faced in his coaching. Some of the other coaches also mentioned the same "age related" as one of their biggest needs in coaching course as well as in his daily coaching. Therefore, the words "age related" were used directly as a code to represent one of the demand these coaches asking from their coaching course provider by the coaches in NFDP in Kuala Lumpur and Shah Alam.

\section{Results and Conclusions}

Result indicate that the two most salient points are the preferred football coaching career development pathways and accredited coaching development pathways.

\section{Preferred Accredited Coaching Course Pathway.}

The results of this study show that most of the coaches involved in NFDP consider the coaching courses and formal educational courses to be highly important. The coaching courses and formal educational courses were reported to have provided an initial source of enthusiasm and interest generated by interpersonal contacts. For example, coach SA 4 mentioned that, "they provided guidance and allowed one to mix with more experienced coaches". 
Vol. 7, No. 3, July 2018, E-ISSN: 2226-6348 @ 2018 HRMARS

According to NFDP coaches involved in this study, coaching courses and formal educational courses provided them with a learning situation that included supervision by an institution in which the teaching is curriculum-driven and the learning results in recognized certifications. To complement the certification programs, coaching organizations often organized conferences or workshops that constitute professional development, and coaches attended these from time-to-time to complement their football certification by either the FAM or the State FA. Furthermore, coaches in NFDP involved in this study also mentioned that coaching courses and formal educational courses is one of the most important sources of knowledge in their coaching career. Almost every coach in NFDP involved in this study has stated their appreciation for the coaching courses and formal educational courses as an integral part of coaching development. For example, one of the coaches KL 1 mentioned that:

Only when I obtained the AFC " $C$ " Licenses my mind opened and I realized much more that at this stage, grassroots and youth coaching needs specialty, well qualified coaches at the highest levels and someone who understands how to handle children, someone who knows the pedagogy and psychology of children and human beings overall.

According to the NFDP coaches involved in this study however, coaching courses and formal educational courses is just one part of the approach to strengthening coaching knowledge. A coach who lacks knowledge in a given area can develop it by educating themselves with self-directed activities such as, clinics, seminars, and short courses.

The NFDP coaches in Kuala Lumpur and Shah Alam involved in this study also seemed to highly appreciate their coaching courses and formal educational courses but they have mentioned in the interview that they have found out that the coaching course they have taken up or will be taking up later are not 100 percent suitable with their needs as a youth coach, in term of its content to be match with their coaching context which is youth. For example Coach SA3 stated that, "the way I see football has changed after I attended the coaching courses and formal educational courses before, because although I know it is good for my development, it is actually in my opinion not suitable for me at my current coaching level, I am coaching at the youth level with NFDP but the B license course content will equipped me with the context of senior and professional level of coaching", whereas Coach SA4 mentioned that, "I learned a lot in coaching courses and formal educational courses especially in terms of football organization but they were all for preparation towards a higher coaching level, not for youth and grassroots where I am currently involved in."

Most of the NFDP coaches involved in this study had experiences with coaching courses and formal educational courses organized by the relevant football governing body, this group of coaches of NFDP had the same views regarding their coaching courses and formal educational courses experiences, and obviously they preferred change in the coaching course content to suit their current coaching context. For example, coach SA1 thought that "all the mentioned coaching courses and formal educational courses always have something to do with coaching, but most of the higher level coaching course are preparing the coach to coach at the senior or adult level, but I am not interested to coach at the senior level." According to coach KL1. 
I am a person who always looking forward to be excellent in whatever I do, including this coaching job with NFDP. I want to go further but there is no where I can progress, because there is no security in this job. I Therefore will continue to coach at this level...until I don't know. I hope they will one day create a more secure job for us...only in this youth football ...below 17 years old only until I became expert in youth job.

Despite their resourcefulness, some of the coaches took part in the coaching courses and formal educational courses because it is compulsory to have a coaching certificate to coach in a club but not because they can choose what coaching course content suit their coaching context. For example Coach KL 6 in this study mentioned that:

In the modern era, sources of football knowledge flood the internet and coaches need to only select what is suitable for them and the appropriateness of the material to their team. I think that coaches do not really need to learn only from the coaching courses and formal educational courses but...the coach's end up taking the coaching courses and formal educational courses just because it is compulsory.

Coach NFDP SA2 also mentioned that initially he participated in coaching courses and formal educational courses because it was compulsory in his tertiary course programme. He mentioned that:

Initially, when I started, I had zero knowledge of what was my expectation when I first attended coaching courses and formal educational courses in my teacher training college. I attended the basic course as it was compulsory to attend not that I preferred the coaching course content.

That is why NFDP Coach KL4 recommended anyone to do the " $A$ " license course of they wanted to coach the senior but if they wanted to coach at the youth and grassroots level then there is not a necessity to take up A license course. The same thought was reported by NFDP Coach SA2 who mentioned that, "I was very interested in attending coaching courses and formal educational courses and considered it to be a key coaching tool, especially at the level I was working at, but not at more advance course like B or A license because they will teach us to be senior level coach". Even though NFDP Coach SA2 also mentioned other sources of knowledge related to his coach education experiences but for him the coaching courses and formal educational courses was the main source, but they need to do some adjustment and be specific.

All of the NFDP coaches felt that as they developed as coaches there was a large provision of education or training within their football environment. Initially, the provision of coach coaching courses and formal educational courses met most of their needs, but according to most of the coaches, however, the courses start to be expanding their knowledge in sport-specific areas of drills and techniques, began to be not suitable with their current coaching context as they also have been exposed to the management part of football, especially those who attended the " $B$ " and " $A$ " license courses, but they don't need that sort of knowledge now as they are 
INTERNATIONAL JOURNAL OF ACADEMIC RESEARCH IN PROGRESSIVE EDUCATION AND DEVELOPMENT

Vol. 7, No. 3, July 2018, E-ISSN: 2226-6348 @ 2018 HRMARS

currently coaching at the youth level, and will be coaching at that context until they become an expert. For example, coach KL2 declared:

I always wanted to develop... and develop rapidly, but the coaching course content that I attended always emphasize on coaching the professional team...the adult or senior coaching level, which I don't think will help me in my coaching at the 7 to 9 years' boys in NFDP. I hope NFDP will create a coaching course specifically cater for the needs of coaches like me coaching at this youth and school's boys level. Age related content. I suggest.

Similar points were raised by NFDP Coach SA1 who considered that, "much of the impact of the coaching courses and formal educational courses is dependent on the person who delivers the course, the coach educator. When I went to another level of coaching courses and formal educational courses, my view about football also changed or improved up to another level". Coach KL 1 also mentioned that "I have gone from one level to another level and have gone up in coaching by attending from the beginner to the highest level coaching courses and formal educational courses". Coaches irrespective of their level were mindful of the benefits of accredited training, for example, NFDP coach KL7 also stressed how the "coaching courses and formal educational courses plays an important part in my development and it has to be very important". NFDP coach SA8 expressed how important formal training was to his development; "the importance that I place on the coaching courses and formal educational courses is very high indeed because of how they passed me through the " $C$ " license".

NFDP coaches in both Kuala Lumpur and Shah Alam discussed the importance of other sources of knowledge beyond the coaching courses and formal educational courses. For example, coaches praised the coaching courses and formal educational courses that many of them gained at university. One of the coaches in Malaysia mentioned that a tertiary educational background was very important in the development of a coach. Coach A3 mentioned that he combined his experience from being a strong and demanding football player with his education:

Why would I take up FAM conducted like B License, A License course, where I need to pay more expensive fees, furthermore they don't cater for my needs as a coach at the 10 to 13 years of players age...If I take that FAM course they will teach me to became a professional senior level coach...I don't want to coach at that level. I want to coach at this youth below 17 years old school's boys, they need to have a coaching course for people like me you know...age related content of the course.

The same thought was discussed by the NFDP coaches in Kuala Lumpur and Shah Alam where they stressed the point that coaches' desire for better coach education programs reflected their belief that the construction of their professional knowledge was largely their own responsibility. A number of the NFDP coaches believed their professional developmental needed to extend not only to the theory but also to practical based information that was anchored in the everyday realities of life, and has already proved itself as a practical solution to professional problems. In this respect, Coach KL 4 mentioned that: 
Vol. 7, No. 3, July 2018, E-ISSN: 2226-6348 @ 2018 HRMARS

I took up C license already. I wanted to take up B license, but I have 2 problems, first is the fees for me is too costly and I simply cannot afford at this moment and second is the content of the course. I've studied its content and found out that it is more to prepare you to coach at the senior level football not the youth football and I wanted to keep myself at the youth level in NFDP. I will speak up to them to adjust the content of the $B$ and $A$ license course to meet the needs of the youth coach so that we can become an expert in youth coaching. Why waste time attend the course that is away from our necessity.

NFDP coaches in Kuala Lumpur and Shah Alam, Malaysia appear to have decided that coaching courses and formal educational courses has vast value in developing their knowledge as a coach. They However, seemed to preferred to attend the course that suit their coaching context which is coaching boys under 17 years old and use that preferred coaching courses and formal educational courses not only as a venue for them to gain knowledge, but also as a forum for discussion to have specific questions related to their players answered.

Based on this reality, reorganizing these learning activities that tailor the specific needs of NFDP youth coaching context has been suggested as one of the alternatives to achieve more positive impacts on coach education (Groom, Coushion \& Nelson, 2012)

\section{Preferred Career Development}

The findings reveal that each coach has the issues, challenges and knowledge resources that they have during their stay in the National Football Development Plan (NFDP) program. Among the issues and challenges faced by NFDP coaches are training, coaching, pedagogy, syllabus, remuneration, uniformity of NFDP and non-NFDP programs, infrastructure facilities, cooperation from other parties and NFDP DNA itself.

Based on this reality, however, this paper will focus only on two most salient point of these research findings apart from others, which are preferred accredited coaching course pathways and preferred career development pathways as (Groom, Coushion \& Nelson, 2012) suggested that reorganizing these learning activities as one of the alternatives to achieve more positive impacts on coach education.

In order to answer the first question, what is the syllabus content of accreditation coaching courses they preferred, the coaches obtain knowledge resources through formal education (coaching, re-education and refreshment course) and informal education (video, meeting with other coaches, daily training sessions, inspiration, lesson plan inventories, past experiences and social media).

Among the issues highlighted by the coaches at NFDP are the opportunity to attend the course. This is as instructed by SA4 coach: "Ok, as we know, not all coaches are given the opportunity to attend the course. So what's wrong is that the NFDP re-educates, refreshments for coaches who have never attended the course. Because I was looking at my own center, like me and two other three were there. " Apart from that, there are also some challenges faced by 
Vol. 7, No. 3, July 2018, E-ISSN: 2226-6348 @ 2018 HRMARS

coaches in NFDP, namely the involvement of coaches during the course as stated by KL2, "One year about two to three times".

The knowledge source for coaches involved with this NFDP program, among others, is the coaching course. The KL6 coach stated that "We have a symposium, after a long time we are back for a refreshment, then re-education seamlessly throughout that year." Another source of knowledge gained by coaches involved with this NFDP program is past experience. This is as stated by the coach SA1 "in fact, the player who has been the coach has a bright chance. The player who was a coach because he had been training with other coaches, so he had a lot of ideas than a coach who had never been a player and when he referred to the coach, his knowledge was just that. No experience. Actually this is an important experience. There are also people who say the coach is not necessarily a player. But in the field of football I prefer the coach to be the basis of his players. "

The study conducted by Stoszkowski and Collins, (2016), states that formalized training courses are also one of the instructor's reference sources for new coaching knowledge. In addition to formal training courses, the instructor's preferred method of accepting new coaching knowledge is from informal learning, self-learning situations, and communication between cooperators from a day to day basis their training session.

This is parallel to Mesquita, Isidro, and Rosado, (2010) that coaching courses are among the sources of knowledge that should be used as a basis for improving skills as coaches. This is because, formal learning is the main source of learning and is beneficial to coaches even more that have no background in coaching. There are coaches who point out that coaching courses are extremely important and the structure of the armor can provide knowledge and experience among coaches and helps coaches to interact and share knowledge throughout the course. Documentation during the coaching course is also very important to help coaches in making decisions using theories and applications during practical sessions on the field.

Aside from that, for reference sources derived from past experience, the findings are parallel to Gonzalez-Rivera, Campos-Izquierdo, Villalba, and Hall, (2017) stating that the experience of the coach as a former athlete is one of the key sources of knowledge of the trainer in Spain. This is because the experience as a player/athlete has previously supplied technical, tactical and physical aspects to see if the players they are training are good or weak and can help them better understand their role as a coach.

This study's result illustrates the NFDP coaches preferred coaching course content and their preferred football coaching career development pathways. Based on the findings, researchers found that career paths selected by coaches involved in the NFDP, they want to focus entirely on the field of coaching at grassroots and youth level. This is because the coaches are meant to be expert in coaching at grassroots and youth level, without having to "go up" and switch to adult-level coaching such as managing teams in the Super League of Malaysia or the Premier League. In their opinion of being expert does not mean they should be coaches in the highest league of the Football Association of Malaysia. 
In addition, the researchers also agree with the coaches involved that career advancement by NFDP coaches is needed to develop further and shift from the seven to nine year categories to categories 10 to 13 years and then to 14 to 17 years only. The increase in career here is not meant to increase to mature teams such as being a coach at the Malaysian Super League or Premier League level but staying in training at the grassroots level only.

It is recommended to NFDP, the Asian Football Confederation (AFC) and the Football Association of Malaysia (FAM) to create a coaching license category such as $A, B$ and $C$ licenses for grassroots and youth or grassroots coaches. These special coaching licenses are not the same as existing coaching licenses. Currently, the content of the A license coaching course is geared towards coaching and managing adult and professional teams such as the Malaysian Super League, Premier League and FAM League. However, the content of the course is having a lot of room for improvement for coaches who preferred to remain with grassroots and Youth in NFDP. The NFDP coaches preferred a coaching accreditation system (license) that provides specification of course content involving coaching at grassroots and youth level only. This can help them stay in the youth team as well as having the highest coaching license without having to switch to adult and professional teams. Accordingly, an initiative can be taken by the authorities to assist these coaches.

Based on the theory developed by Gladwell, (2008) which states that each individual needs 10,000 hours of training to become experts in the field they are involved in. Therefore, if the NFDP coach wants to become an expert in their field of training of teens at the grassroots and youth level, they should be placed in the team for a long period of time without having to switch to a more mature or professional team. In that regard, one motivation and encouragement should be given to them in the form of competence certification which enables them to continuously improve their coaching knowledge to train players at grassroots and youths.

It is also recommended that all NFDP coaches be given the opportunity to follow the Knowledge Transfer Exchange program at clubs or teams among European, Latin American and Asian countries such as Korea and Japan, as required by the coaches involved with this research. According to Reade, Rodgers, and Spriggs, (2008), the coaches usually accept new ideas as a result of interaction with other coaches, training courses and seminars. With the relationship between NFDP and other teams, NFDP coaches can interact with the coaches and exchange knowledge.

Based on the DNA of the National Football Development Plan (NFDP) program, victory is not everything for those who coach player's grassroots and youths. Hence, it is parallel to the third-level Long Term Athlete Development model, the 'training to compete' stage. $50 \%$ of the training sessions at this stage are for the development of technical skills, tactical and physical fitness while the remaining $50 \%$ are specific training for the competition. At this stage, skilled players in basic skills as well as sports learned will learn how to apply the following skills in various competitive situations during training sessions. Special emphasis is given as an optimum 
INTERNATIONAL JOURNAL OF ACADEMIC RESEARCH IN PROGRESSIVE EDUCATION AND DEVELOPMENT

Vol. 7, No. 3, July 2018, E-ISSN: 2226-6348 @ 2018 HRMARS

preparation by modeling training and competition. Fitness programs, recovery programs, psychological preparations and technical developments are now individually tailored to a higher level. The emphasis on individual preparation can address every individual's strengths and weaknesses, (Balyi, 2001).

\section{Conclusions}

If the National Football Development Plan (NFDP) blueprint program does not identify the issues faced by their coaches and understand what coaching knowledge sources are able to improve their coaching skills, then the goals of the program will not be fully achieved and players produced do not achieve the standard set. When this happens, wasting tax payer's money will also occur, time losses will be faced by coaches and players and will ultimately have a negative impact on the country' football.

\section{Acknowledgement}

This paper project received funding from Research Management and Innovative Centre (RMIC) of Education University of Sultan Idris. This project also provides knowledge and information that can be used for National Football Development Plan (NFDP) program in order to enhance their coaching curriculum.

\section{Corresponding Author}

Zulakbal Bin Abd Karim

Faculty of Sports Science and Coaching,

Sultan Idris Education University, 35900, Tanjung Malim, Perak, Malaysia.

Email: zulakbal@fsskj.upsi.edu.my

\section{References}

Ali, A. \& Talib, M. D. (2013). Siri sukan popular bola sepak. Shah Alam: Oxford Fajar.

Balyi, I. (2001). Sport system building and Long-term Athlete Development in British Columbia. Development, 1-16. Retrieved from http://iceskatingresources.org/SportsSystemDevelopment.pdf

Gladwell, M. (2008). Outliers. Booksgooglecom (Vol. 20). United States of America: Hachette Book Group. https://doi.org/10.3200/SRCH.20.2.48-57

Gonzalez-Rivera, M. D., Campos-Izquierdo, A., Villalba, A. I., \& Hall, N. D. (2017). Sources of knowledge used by Spanish coaches: A study according to competition level, gender and professional experience. International Journal of Sports Science and Coaching, 12(2), 162174. https://doi.org/10.1177/1747954117694733

Groom, R., Cushion, C.J., \& Nelson, L.J. (2012) Analysing coach-athlete 'talk in interaction'within the delivery of video-based performance feedback in elite youth football. Qualitative research in sport, exercise and health 4 (3), 439-458 


\section{INTERNATIONAL JOURNAL OF ACADEMIC RESEARCH IN PROGRESSIVE EDUCATION AND}

\section{DEVELOPMENT}

Vol. 7, No. 3, July 2018, E-ISSN: 2226-6348 @ 2018 HRMARS

Hamid, N. J. A., \& Kendall, G. (2008). Maximizing stadium attendance: A case study of Malaysian football. Proceedings of the 7th International Conference on the Practice and Theory of Automated Timetabling PATAT (pp. 1-4_. Montreal: Universite de Montreal.

Karim, Z. B. A., \& Razak, N. (2018). Lesson Learned from Coaches of Malaysia National Football Development Programme (NFDP): Preferred Career Development Pathway and Acrredited Coaching Course. International Journal of Academic Research in Progressive Education and Development, 7(3), 465-479.

Zulakbal Abd Karim, \& Ali Md Nadzalan. (2017). Malaysia football coaches : Development characteristics. International Journal of Academic Research in Business and Social Sciences, 7(9), 305-312. https://doi.org/10.6007/IJARBSS/v7-i9/3326 